\title{
The Effect of Oil Price on Nigerian Macroeconomic Variables from 1990-2015
}

\author{
Chikwe, Goddey C. \\ Department of Business Management, Evangel University, Akaeze, Ebonyi State, Nigeria \\ Ujah Chidinma \\ Department of Project Management Technology, Federal University of Technology Owerri, Imo \\ State, Nigeria \\ Uzoma, Chukwuemeka $H$ \\ Department of Business Management, Imo State University, Owerri, Imo State, Nigeria

\begin{abstract}
This study was aimed at using multiple regression technique to analyze the effect of oil price on the Nigerian macroeconomic variables from 1990 to 2015. In a bid to achieve the above objectives, null and alternative hypotheses were formulated to guide the study. The statistical technique discussed in this study was used to justify the hypotheses, and the SPSS statistical software was employed to ease the analysis. The analysis revealed that there is significant relationship international oil price and macroeconomic variables. Further analysis based on the individual test shows that unemployment rate contributes positively to international oil price, while interest rate contributes negatively to international oil price. Again, the result showed that inflation rate, exchange rate, and RGDP do not have any effect on international oil price. The coefficient of determination $\left(R^{2}\right)$, which indicated the proportion in $Y$ that is explained by X's turned out with a percentage of $83.4 \%$ showing that there was a strong relationship between the international oil price variable and the macroeconomic variables.
\end{abstract}

Keywords: Macroeconomic Variables, International Oil Price, Regression Analysis, Coefficient of Determination, ANOVA

\section{INTRODUCTION}

The provision of plausible explanation for the oil price-macroeconomic relationship has occupied the attention of researchers and policymakers over the last four decades. The attention was drawn by the central role which oil plays in the world economy and the observed linkage between oil price movement and business cycle. Oil plays a dominant role in Nigerian economy given its huge contribution to the revenue of the country. For instance, CBN statistical bulletin (2011) shows that oil receipts accounted for $82.1 \%, 83 \%$ and about 90 per cent of the nation's foreign exchange earnings in 1974, 2008 and 2010 respectively.

However, it is empirically established that oil price is one of the most volatile prices which has significant impact on macroeconomic behavior of many developed and developing economies (Ferderer, 1996; Guo \& Kliesen, 2005). Therefore, the dependence of the Nigerian economy on oil proceeds as the major source of revenue is capable of raising suspicion about the impact of oil price volatility on macroeconomic volatility in the country. Macroeconomic volatility implies the vulnerability of macroeconomic variables to shocks. It is the tendency of macroeconomic variables such GDP, inflation, exchange rate, interest rate etc to be unstable and weak in terms of withstanding shock. It is a situation whereby little shock in the economy subjects the macroeconomic variables to fluctuations and uncertainty. In the light of this, many studies investigated the impact of oil price changes on macro economic variables in Nigeria. The consensus finding is that while oil price changes have direct significant relationship with many macroeconomic variables, it does not significantly affect output growth (Wilson, et al; 2014; Taiwo, et al; 2012; Apere \& Ijiomah, 2013).

The impact of oil price volatility on Nigeria's economy is quite complicated to analyze because oil has been the life wire of all economic activities in Nigeria. Total dependence of Nigeria on oil production for income generation obviously has serious implications for the economy. Since 
agriculture was abandoned for oil, oil became the major source of Nigeria's revenue and it was expected to bring about substantial economic growth and development. However, there have been series of fluctuations in oil price since the last four decades, thereby hampering the macro-economic objectives of Nigeria, (CBN, 2008). There is no doubt that the total dependence on oil, its attendant corruption and constant volatility in oil price are the major causes of poverty and under-development in oil producing African Countries.

The effect of oil prices on the macro-economic variables has been the subject of many studies. Most of these studies are concerned with the developed economies while few have recently showed concern with the developing country. Hence, this study will look into the effects of international oil price on five macroeconomic variables (inflation rate, exchange rate, RGDP, unemployment rate, and interest) from 1990 to 2015.

The objective of this study is to use a multiple regression technique to analyze the effect of oil price on the Nigerian macroeconomic variables. Hence, Specific objectives of the study are:

i. To examine the effect of exchange rate on the international oil price

ii. To examine the effect of interest rate on the international oil price

iii. To examine the impact of inflation rate on the international oil price

iv. To determine if unemployment rate has any effect on the international oil price

v. To determine if real gross domestic product has any effect on the international oil price

\section{RELATED Literature REVIEW}

Offiong et al (2016) carried out a research on the Impact of Oil Price Shocks on the Economic Growth and Development of Cross River State, Nigeria. The study investigated the impact of this plunge on the economic development of Cross River State, Nigeria and found that international oil price shocks affected the State's economy inversely, while a positive but insignificant relationship existed between the other model variables and the economic growth of the State. Consequently, the study recommended that CRS government should de-emphasize the over-reliance on crude oil revenue and seek and optimize earnings from other non-oil sectors of the economy. Further, the State's economy should be diversified to boost internally generated revenue with less dependence on Federal government revenue allocation. Finally, there should be effective machinery for checks and balances put up by the government to stem fiscal abuse and wastage of resources by the ministries, departments and agencies in the State.

Babajide and Soile (2015) worked on Oil Price Shocks and Nigeria's Economic Activity: Evidence from Autoregressive Distributed Lag (ARDL) Co-integration and Vector Error Correction Model (VECM) Analysis. The study examined the impact of oil price shocks and their transmission channels to selected macroeconomic variables which served as proxies for economic activities in Nigeria using quarterly data from 1980 in Quarter 1 to 2011 in Quarter 4. Empirical analysis was carried out using VAR framework. Further the Impulse Response Function (IRF) and the Variance Decomposition (VDC) were carried out to trace the impact of oil shocks to the Nigerian economy. The result showed that oil price shocks have negative impact on nearly all the variables used in the analysis; furthermore the asymmetric relationship between oil price shocks and GDP was not established as the effects was found to be minimal in all the tests results. The result clearly illustrated that oil price decreases affected most of the macroeconomic indicators than increases. Specifically, oil price decrease affected trade balance, inflation, government revenue and exchange rate. The implications are that oil price decreases affected macroeconomic activity in Nigeria than increases as most of the variables except inflation did not respond to increases. Based on the findings it was recommended that a relaxation of monetary policy during an oil price fluctuation era as the government has already through the central bank adopted a inflation targeting policy in order to protect the economy from possible outcome of a full blown stagflation (persistent high inflation) amongst others.

Mhamad and Saeed (2016) worked on the Impact of Oil Price on Economic Growth: Empirical Evidence from Iraq. To achieve this objective (of fulfilling its full potential), the study adopted OLS approach, and the secondary data was used for the period of 2000-2015 and multiple regression with its assumption were used in order to analyze the data. Findings showed that, oil price and oil export were very important determinates of economic growth in Iraq because the p-value of those were less 
than the common alpha $\alpha=0.05$. For instance, for each unit increasing of oil price, the economic growth will increase by $36.9 \%$ after holding all other variable constant. However, they found that exchange variable has no impact on the participations of increasing the economic growth because of having corruption in public banks in Iraq.

Ebele (2015) conducted a research on Oil Price Volatility and Economic Growth in Nigeria: An Empirical Investigation. The study investigated the impact of crude oil price volatility on economic growth in Nigeria from 1970 to 2014. The study aimed at extending the frontier of knowledge by estimating the impact of the oil price volatility on the Nigerian economic growth using aggregate demand framework that theoretically connect analytical variables, rather than just explaining output behaviour by oil price and host of arbitrarily variables as done by earlier studies. The study adopted Engel-Granger co-integration test and Granger Representation theorem in testing the long run and short run relationships between crude oil volatility and economic growth respectively. The study found that, oil price volatility (OPV) has negative impact on the economic growth while other variables such as crude oil price, oil revenue and oil reserves have positive impact on the Nigerian economy. Based on the findings, the study recommended that-the country should diversify its export revenue base as a means of minimizing reliance on crude oil outputs. The study further proffered that government should adopt a prudent fiscal policy in relation to oil prices. This could be done through the elimination of some taxes on crude oil and the gradual removal of oil price subsidies

Oluwatoyin (2014) conducted a work on Analysis of the Effect of Oil Price Shock and Exchange Rate Instability on Economic Growth in Nigeria. The study was to assess the impact of oil price shock and real exchange rate instability on real economic growth in Nigeria on the basis of quarterly data from 1986 to 2012. Time series data was used to examine the nature of causality among the variables. The Johansen Vector Autoregressive (VAR)-based co-integration technique was applied to examine the sensitivity of real economic growth to changes in oil prices and real exchange rate volatility in the long-run while the short run dynamics was checked using a Vector Error Correction Model (VECM). Results from Augmented Dickey-Fuller (ADF) and PP tests show evidence of unit root in the data and Granger pairwise causality test revealed unidirectional causality from oil prices to real Gross Domestic Product (GOP). The findings of the study shows that oil price shock and appreciation in the level of exchange rate exert positive impact on real economic growth in Nigeria. It recommends greater diversification of the economy through investment in key productive sectors of the economy to guard against the vicissitude of oil price shock and exchange rate volatility.

Oriakhi and Osazel (2013) examined the consequences of oil price volatility on the growth of the Nigerian economy within the period 1970 to 2010. Using quarterly data and employing the VAR methodology. Their study found that, of the six variables employed, oil price volatility impacted directly on real government expenditure, real exchange rate and real import, while impacting on real GDP, real money supply and inflation through other variables, notably real government expenditure. This implied that oil price changes determine government expenditure level, which in turn determines the growth of the Nigerian economy.

Having reviewed these past researches, we shall now examine effect of oil price on Nigerian macroeconomic variables using multiple regression analysis. The macroeconomic variables considered in this study are; exchange rate, interest rate, inflation rate, unemployment rate and real gross domestic product.

\section{RESEARCH Methodology}

The method of data collection used in this study is secondary method. Data were obtained from the CBN Major Economic Financial and Banking indicators (2008); World Economic and Financial Surveys, (IMF,2015); Office for National Statistics,(UK,2015); CBN Money and Credit Statistics, (2015), CBN Annual Report (various issues), CBN Statistical bulletin (2012).

The method of analysis used in this study is the Regression Analysis. Regression analysis is a statistical technique that expresses mathematically the relationship between two or more quantitative variables such that one variable (the dependent variable) can be predicted from the other or others (independent variables). Regression analysis is very useful in predicting or forecasting (Inyama, and Iheagwam; 2006). It can also be used to examine the effects that some variables exert on others. Regression analysis may be simple linear, multiple linear or non linear. Since, in this study work, we have more than one independent variable, which implies that it is multiple regression analysis. The 
dependent variable is international oil price, while the independent variables are interest rate, exchange rate, real gross domestic product, unemployment rate, and interest rate. The Analysis of Variance (ANOVA) Table for the multiple regression analysis is presented in Table 1.

Table1. Anova Table

\begin{tabular}{|l|l|l|l|}
\hline Source of variation & Df & SS & MS \\
\hline Regression & $\mathrm{k}-1$ & $\sum \hat{\mathrm{y}}_{\mathrm{t}}^{2}$ & $\frac{\Sigma \hat{y}_{t}^{2}}{k-1}$ \\
\hline Error & $\mathrm{n}-\mathrm{k}$ & $\sum \mathrm{y}_{\mathrm{t}}^{2}-\Sigma \hat{\mathrm{y}}_{\mathrm{t}}^{2}$ & $\Sigma y_{t}^{2}-\frac{\Sigma \hat{y}_{t}^{2}}{n-k}$ \\
\hline Total & & & \\
\hline
\end{tabular}

$\mathrm{F}_{\text {calculated }}=\frac{\frac{\Sigma \hat{\mathrm{y}}_{\mathrm{t}}^{2}}{\mathrm{k}-1}}{\frac{\sum \mathrm{y}_{\mathrm{t}}^{2}-\Sigma \hat{\mathrm{y}}_{\mathrm{t}}^{2}}{\mathrm{n}-\mathrm{k}}}=\frac{\mathrm{RMS}}{\mathrm{EMS}}$

The decision rule is to reject $\mathrm{H}_{0}$ is $\mathrm{F}_{\text {cal }} \geq \mathrm{F}_{\mathrm{k}-1, \mathrm{n}-\mathrm{k} ; \alpha}$ otherwise accept $\mathrm{H}_{0}$. Alternatively, we reject the null hypothesis if the p-value is less than the level of significance at $5 \%$.

\section{Coefficient of Determination}

The (multiple) coefficient of determination is given by

$$
\mathrm{R}^{2}=\frac{\sum \hat{\mathrm{y}}_{\mathrm{t}}{ }^{2}}{\sum \mathrm{y}_{\mathrm{t}}{ }^{2}}
$$

where $\mathrm{x}_{1}, \mathrm{x}_{2}, \mathrm{x}_{3}, \mathrm{x}_{4}, \mathrm{x}_{5}, \mathrm{y}$ are in deviation form. The adjusted $\mathrm{R}^{2}$ written as $\overline{\mathrm{R}}^{2}$ is defined by

$$
\overline{\mathrm{R}}^{2}=1-\left(1-\mathrm{R}^{2}\right) \frac{\mathrm{n}-1}{\mathrm{n}-\mathrm{k}}
$$

\section{Test of Hypotheses}

Our model $Y=\hat{\beta}_{1} x_{1}+\hat{\beta}_{2} x_{2}+\hat{\beta}_{3} x_{3}+\hat{\beta}_{4} x_{4}+\hat{\beta}_{5} x_{5}+U$ involves five explanatory (independent) variables. Hence we can conduct two types of tests about the parameters of the model, namely; individual tests and joint tests.

\section{Individual Test}

Individual test involves testing whether an explanatory variable has any influence on the dependent variable when the other explanatory variable is held constant.

The null and alternative hypotheses may be stated as follows:

$\mathrm{H}_{0}: \beta_{\mathrm{i}}=0, \mathrm{i}=1,2,3,4,5$ (i.e. there is no linear relationship between $\mathrm{x}_{\mathrm{i}}$ and $\mathrm{y}$, the other $\mathrm{x}$ held constant).

$\mathrm{H}_{1}: \beta_{\mathrm{i}} \neq 0$ (i.e. a relationship exists between $\mathrm{x}_{\mathrm{i}}$ and $\mathrm{y}$ ).

Under the assumption that each $\mathrm{U}_{\mathrm{i}}$ is $\mathrm{N}\left(0, \delta^{2}\right)$, the test statistic will be given by

$\mathrm{t}_{\mathrm{cal}}=\frac{\hat{\beta}_{\mathrm{i}}}{\operatorname{SE}\left(\hat{\beta}_{\mathrm{i}}\right)}$

The decision rule is to reject $\mathrm{H}_{0}$ at the $\alpha$ level of significance if $t_{\text {cal }}>t_{\text {tab }}$ or to reject $H_{0}$ if $p$-value is less than the level of significance at 5\% (and hence conclude that a relationship exists between $y$ and $\mathrm{x}_{\mathrm{i}}$ ) and to accept $\mathrm{H}_{0}$ otherwise. 


\section{Joint Test}

This involves testing whether $\mathrm{X}_{\mathrm{i}, \mathrm{i}} \mathrm{i}=1,2,3,4,5$ are jointly related to $\mathrm{Y}$. This is equivalent to testing whether

$\beta_{1}=\beta_{2}=\ldots=\beta_{\mathrm{k}}=0$

Thus, the null and alternative hypotheses are:

$\mathrm{H}_{0}: \beta_{1}=\beta_{2}=\ldots=\beta_{\mathrm{k}}=0$ (i.e. $\mathrm{x}_{1}, \mathrm{x}_{2} \ldots, \mathrm{x}_{\mathrm{k}}$ are not jointly related to $\mathrm{y}$ )

$\mathrm{H}_{1}: \beta_{\mathrm{i}} \neq 0$ for at least one i i.e. $\mathrm{x}_{1}, \mathrm{x}_{2}, \mathrm{x}_{3}, \mathrm{x}_{4}$ and $\mathrm{x}_{5}$ are jointly related to $\mathrm{y}$.

Thus, a joint test can be conducted using the Analysis of variance techniques as follows:

$$
\begin{aligned}
& \mathrm{TSS}=\Sigma \mathrm{y}_{\mathrm{t}}^{2} \\
& R S S=\Sigma \hat{y}_{i}^{2}=\hat{\beta}_{1} \Sigma x_{1} y+\hat{\beta}_{2} \Sigma x_{2} y+\hat{\beta}_{3} \Sigma x_{3} y+\hat{\beta}_{4} \Sigma x_{4} y++\hat{\beta}_{5} \Sigma x_{5} y \\
& \mathrm{ESS}=\mathrm{TSS}-\mathrm{RSS}=\Sigma \mathrm{y}_{\mathrm{t}}^{2}-\Sigma \hat{\mathrm{y}}_{\mathrm{t}}^{2}
\end{aligned}
$$

\section{Data Analysis}

In this section, we analyzed the data in this study using multiple linear regression discussed in this study. From the data used in this study, international oil price is the response variable, while exchange rate, interest rate, inflation, unemployment rate and real gross domestic product are the explanatory variables. Thereafter, the interpretation will take place.

\begin{tabular}{|c|c|c|c|c|c|c|c|c|}
\hline \multirow{2}{*}{\multicolumn{2}{|c|}{ Model }} & \multicolumn{2}{|c|}{$\begin{array}{c}\text { Unstandardized } \\
\text { Coefficients }\end{array}$} & \multirow{2}{*}{$\begin{array}{c}\text { Standardized } \\
\text { Coefficients } \\
\text { Beta } \\
\end{array}$} & \multirow[t]{2}{*}{$\mathrm{t}$} & \multirow[t]{2}{*}{ Sig. } & \multicolumn{2}{|c|}{ Collinearity Statistics } \\
\hline & & $\mathrm{B}$ & Std. Error & & & & Tolerance & VIF \\
\hline \multirow{6}{*}{1} & (Constant) & 62.139 & 26.882 & & 2.312 & .032 & & \\
\hline & INFR & .184 & .212 & .099 & .871 & .394 & .637 & 1.570 \\
\hline & EXCR & -.256 & .131 & -.416 & -1.957 & .064 & .183 & 5.465 \\
\hline & RGDP & 1.382 & .980 & .171 & 1.411 & .174 & .562 & 1.779 \\
\hline & UNEMPR & 3.999 & .693 & 1.015 & 5.770 & .000 & .268 & 3.731 \\
\hline & INTR & -2.323 & 1.067 & -.320 & -2.178 & .042 & .383 & 2.612 \\
\hline
\end{tabular}

Table2. SPSS Output Printout

Coefficients $^{\mathrm{a}}$

a. Dependent Variable: IOP

We shall fit the regression model. However, from the SPSS printout shown in Table 2; the fitted regression model of International Oil Prices (IOP) on Inflation Rate (INFR), Exchange Rate (EXCR), Real Gross Domestic Product (RGDP), Unemployment Rate (UNEMPR), and Interest Rate (INTR).

$I O P=62.139+0.184 I N F R-0.256 E X C R+1.382 R G D P+3.999 U N E M P R-2.323 I N T R$ Joint Test

\section{Hypothesis}

$\mathrm{H}_{0}$ : There is no relationship between oil price and Nigerian macroeconomic variables.

$\mathrm{H}_{1}$ : Relationship exists.

$\mathrm{F}_{\text {cal }}=20.127$ (See SPSS output below)

$\mathrm{F}_{\mathrm{tab}}=\mathrm{F}_{5,20,0.05}=2.71$

Since $\mathrm{F}_{\text {cal }}=20.127>\mathrm{F}_{\text {tab }}=2.71$, we reject $\mathrm{H}_{0}$ and accept $\mathrm{H}_{1}$. Alternatively, we decide using the $\mathrm{p}$ value. The null hypothesis is also rejected since p-value (0.000) is less than the level of significance (0.05). Because the null hypothesis has been rejected in the joint test, it becomes necessary to examine our objectives one after the other to know the effect of oil price on macroeconomic variables. 
Chikwe, Goddey C et al.

Table3. SPSS Output Printout

ANOVA $^{\text {a }}$

\begin{tabular}{|l|l|l|l|l|l|l|}
\hline \multicolumn{2}{|l|}{ Model } & Sum of Squares & df & Mean Square & F & Sig. \\
\hline \multirow{4}{*}{1} & Regression & 23451.353 & 5 & 4690.271 & 20.127 & $.000^{\mathrm{b}}$ \\
\cline { 2 - 7 } & Residual & 4660.631 & 20 & 233.032 & & \\
\cline { 2 - 7 } & Total & 28111.984 & 25 & & & \\
\hline
\end{tabular}

a. Dependent Variable: IOP

b. Predictors: (Constant), INTR, RGDP, INFR, UNEMPR, EXCR

\section{Individual Test}

From the SPSS output in Table 4,

T-calculated for $\beta_{1}=0.871, \beta_{2}=-1.957, \beta_{3}=.1 .411, \beta_{4}=.5 .770$ and $\beta_{5}=.-2.178$.

$\operatorname{SE}\left(\beta_{1}\right)=0.212, \operatorname{SE}\left(\beta_{2}\right)=0.131, \operatorname{SE}\left(\beta_{3}\right)=0.980, \operatorname{SE}\left(\beta_{4}\right)=0.693$ and $\operatorname{SE}\left(\beta_{5}\right)=1.067$

The necessary hypotheses according to the objectives of the study are as follows:

$\mathrm{H}_{0}^{1}: \hat{\beta}_{1}=0 \quad$ (Inflation rate does not have any significant effect on international oil price).

$\mathrm{H}_{1}^{1}: \hat{\beta}_{1} \neq 0$ (Inflation rate has significant effect on international oil price)

$H_{0}^{2}: \hat{\beta}_{2}=0$ (Exchange rate does not have any significant effect on international oil price).

$H_{1}^{2}: \hat{\beta}_{2} \neq 0$ (Exchange rate has significant effect on international oil price)

$H_{0}^{3}: \hat{\beta}_{3}=0$ (RGDP does not have any significant effect on international oil price).

$H_{1}^{3}: \hat{\beta}_{3} \neq 0$ (RGDP has significant effect on international oil price)

$H_{0}^{4}: \hat{\beta}_{4}=0$ (Unemployment rate does not have any significant effect on international oil price).

$H_{1}^{4}: \hat{\beta}_{4} \neq 0$ (Unemployment rate has significant effect on international oil price) and

$H_{0}^{5}: \hat{\beta}_{5}=0$ (Interest rate does not have any significant effect on international oil price).

$H_{1}^{5}: \hat{\beta}_{5} \neq 0$ (Interest rate has significant effect on international oil price)

The decision rule is to reject $\mathrm{H}_{0}$ if $\mathrm{t}_{\mathrm{cal}} \geq \mathrm{t}_{\mathrm{tab}}$ where

$$
t_{\text {tab }}=t_{\frac{\alpha}{2}, v}=t_{0.025,20}=2.086
$$

Since t-calculated for inflation rate, exchange rate, RGDP is less than its tabulated value, we do not reject $\mathrm{H}_{0}$ and reject $\mathrm{H}_{\mathrm{o}}$ for unemployment rate and interest rate since the $\mathrm{t}$-calculated is greater than its tabulated value. Alternatively, using the p-value, the same conclusion is achieved.

Table4. SPSS Output Printout

Coefficients $^{\mathrm{a}}$

\begin{tabular}{|c|c|c|c|c|c|c|c|c|}
\hline \multirow{2}{*}{\multicolumn{2}{|c|}{ Model }} & \multicolumn{2}{|c|}{ Unstandardized Coefficients } & \multirow{2}{*}{\begin{tabular}{|l} 
Standardized Coefficients \\
Beta
\end{tabular}} & \multirow[t]{2}{*}{$\mathrm{t}$} & \multirow[t]{2}{*}{ Sig. } & \multicolumn{2}{|c|}{ Collinearity Statistics } \\
\hline & & $\mathrm{B}$ & Std. Error & & & & Tolerance & VIF \\
\hline \multirow{6}{*}{1} & (Constant) & 62.139 & 26.882 & & 2.312 & .032 & & \\
\hline & INFR & .184 & .212 & .099 & .871 & .394 & .637 & 1.570 \\
\hline & EXCR & -.256 & .131 & -.416 & -1.957 & .064 & .183 & 5.465 \\
\hline & RGDP & 1.382 & .980 & .171 & 1.411 & 174 & .562 & 1.779 \\
\hline & UNEMPR & 3.999 & .693 & 1.015 & 5.770 & .000 & .268 & 3.731 \\
\hline & INTR & -2.323 & 1.067 & -.320 & -2.178 & .042 & .383 & 2.612 \\
\hline
\end{tabular}

a. Dependent Variable: IOP

\section{Coefficient of Determination}

The coefficient of determination is 0.834 from Table 5, which implies that the model is adequate. 
Table5. SPSS Output Printout

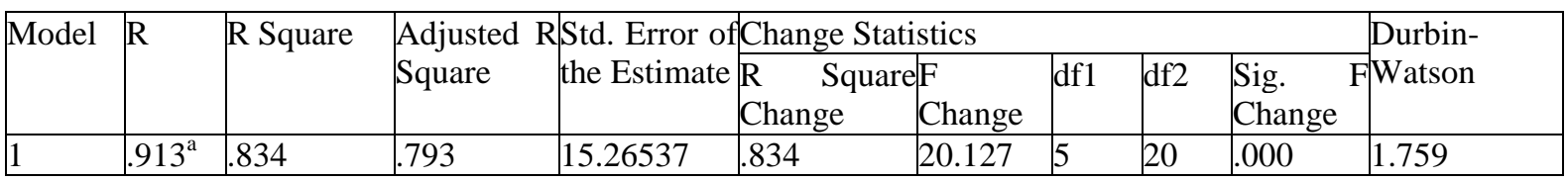

a. Predictors: (Constant), INTR, RGDP, INFR, UNEMPR, EXCR

b. Dependent Variable: IOP

\section{Conclusion}

Since the calculated value is greater than the tabulated value in the first hypotheses, we reject the null hypothesis, which means International oil price has effect on Nigerian macroeconomic variables. Rejection of $\mathrm{H}_{0}$ in the first hypothesis leads to testing the parameters individually which we found out that inflation rate, exchange rate, and RGDP are insignificant, unemployment rate and interest rate are significant. The coefficient of determination $\left(\mathrm{R}^{2}\right)$, which indicates the proportion in $\mathrm{Y}$ that is explained by X's turned out with a percentage of $83.4 \%$ showing that there is a strong relationship between the international oil price variable and the macroeconomic variables. This result entails that $83.4 \%$ (percent) variation in the value of international oil price is explained by a change in the macroeconomic variables. Hence, we can conclude that interest rate and unemployment rate is a determinant of international oil price, while inflation rate, exchange rate and RGDP is a not a determinant of international oil price.

\section{REFERENCES}

Apere, O. \& Ijomah A. M. (2013). Macroeconomic Impact of Oil Price Levels and Volatility in Nigeria. International Journal of Academic Research in Economics and Management Sciences 2(4), $15-25$

Babajide, N.A., and Soile, I.O. (2015). Oil Price Shocks and Nigeria's Economic Activity: Evidence from ARDL Co-integration and VECM Analysis. ResearchGate Research, July 2015.

CBN. (2011). Statistical Bulletin, Vol. 21, Central Bank of Nigeria, Abuja, December.

Ebele, E. (2015). Oil Price Volatility and Economic Growth in Nigeria: An Empirical Investigation. European Journal of Humanities and Social Sciences Vol. 34, No.1, 2015

Ferderer, J.P. (1996). Oil Price Volatility and the Macroeconomy. Journal of Macroeconomics, 18(1), $1-26$.

Guo, H., \& Kliesen, K.L. (2005). Oil price volatility and US macroeconomic activity. Review, Federal Reserve Bank of St. Louis 57 (6): 669-683.

IMF (2000). Poverty reduction and debt relief for poor countries. Annual Report, April, Washington DC.

Inyama, S.C. and Iheagwam, V.A. (2006): Statistics and Probability. A Focuse on Hypotheses Testing. Third edition. Strokes Global Ventures Owerri, Imo State, Nigeria

Mhamad, S.H. and Saeed, S.T. (2016). Impact of Oil Price on Economic Growth: Empirical Evidence from Iraq. Journal of Economics and Sustainable Development. Vol.7, No.14, 2016.

Offiong, A.I., Atsu, I.A., Ajaude, E. \& Ibor, B.I. (2016). The Impact of Oil Price Shocks on the Economic Growth and Development of Cross River State, Nigeria. International Journal of Financial Research Vol. 7, No. 4; 2016.

Oluwatoyin, M.A. (2014). An Analysis of the Effect of Oil Price Shock and Exchange Rate Instability on Economic Growth in Nigeria. Scottish Journal of Arts, Social Sciences and Scientific StudiesISSN 2047-1278.

Oriakhi, D. E., \& Osaze, I. D. (2013). Oil Price Volatility and its Consequences on the Growth of the Nigerian Economy: An Examination (1970-2010). Asian Economic and Financial Review, 3(5), 683-702.

Taiwo, M., Abayomi, T. \& Damilare O. (2012). Crude Oil Price, Stock Price and Some Selected Macroeconomic Indicators: Implications on the Growth of Nigeria Economy, Research Journal of Finance and Accounting, 3(2), 42-48.

Wilson, A. David, U. Inyiama, O. \& Beatrice, E. (2014). Oil price volatility and economic development: Stylized evidence in Nigeria. Journal of Economics and International Finance, $6(6), 125-133$ 


\section{AUTHORS' BIOGRAPHY}
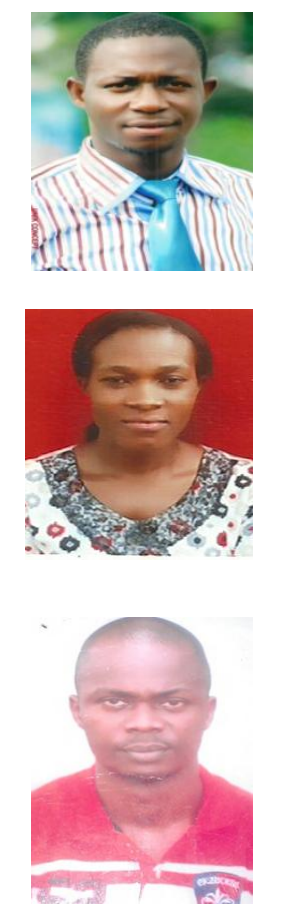

Mr. Chikwe, Goddey Chukwudi, is a young, dynamic and growing Christian academic. A Doctorate Degree (Ph.D) student in Industrial Relations and Personnel Management at Michael Okpara University of Agriculture Umudike, Abia State, Nigeria. He is widely published in renowned scholarly journals and is currently on the employment of Evangel University, Akaeze, Ebonyi State where he is creditably serving as a Lecturer.

Chidinma Ujah, obtained her B.Tech. (Hons) in Project Management Technology from the Department of Project Management Technology, Federal University of Technology, Owerri Imo State, Nigeria. She also holds a Postgraduate Diploma certificate in Education from National Teachers' Institute in affiliation with the National Open University Nigeria. She has previously taught different subjects in both primary and secondary institutions. Presently, she is a Masters' student at Federal University of Technology, Owerri Imo State Nigeria.

Uzoma, Chukwuemeka H., was born on 31st May 1983 to the family of Mr. \& Mrs. Brendan Uzoma from Ezealaeke Owrre-Ebeiri in Orlu Local Government Area of Imo State. He obtained his first degree in Business Management in 2005 and his masters' degree in Business Management in 2015 both from Imo State University Owerri Nigeria. Currently he is a Postgraduate student of Education at National Teachers' Institute in affiliation with the National Open University Nigeria. He is happily married with two children. 